\title{
Prevalencia de la hidatidosis en hígados bovinos y pérdidas económicas en el camal municipal de la ciudad de Puyo-Ecuador
}

\author{
Prevalence of hydatidosis in bovine livers and economic losses in the municipal bed of the city of \\ Puyo-Ecuador \\ Núñez-Torres Oscar Patricio*iD, Chávez-Vargas Andrés Fernando
}

\begin{tabular}{|c|c|}
\hline Data of the Article & Resumen \\
\hline $\begin{array}{l}\text { Faculty of agricultural sciences. } \\
\text { Technical University of Ambato. } \\
\text { Cantón Cevallos. } \\
\text { Tungurahua, Ecuador. } \\
\text { P.O. Box: 18-01-334. } \\
\text { Telf: +593 032746151 - } 032746171 \\
\text { *Contact address: } \\
\text { Faculty of agricultural sciences. } \\
\text { Technical University of Ambato. } \\
\text { Canton Cevallos. } \\
\text { Tungurahua, Ecuador. } \\
\text { P.O. Box: } 18-01-334 . \\
\text { Telf: }+593 \text { 032746151 - } 032746171 \\
\text { Oscar Patricio Núñez-Torres } \\
\text { E-mail address: op.nunez@uta.edu.ec }\end{array}$ & $\begin{array}{l}\text { El objetivo de la investigación fue determinar la prevalencia de hidatidosis en hígado de bovinos faenados en el } \\
\text { camal municipal de la ciudad de Puyo, provincia de Pastaza. El estudio consistió en la inspección post-morten de } \\
\text { las vísceras, hígados, de todos los bovinos. Para evaluar el ensayo se utilizó la estadística descriptiva e inferen- } \\
\text { cial, mediante cuadros con porcentajes, gráficos, promedios, coeficiente de variación (CV) desviación estándar y } \\
\text { utilizando la prueba del Chi-cuadrado. En promedio se obtuvo un peso de } 13.57 \mathrm{lb} \text { de hígados decomisados con } \\
\text { una desviación estándar de } 11.67 \text { y un coeficiente de variación de } 85.99 \% \text {. Existiendo una variabilidad en los } \\
\text { datos esto se debe a la baja frecuencia de ocurrencia de la enfermedad en los bovinos faenados, de } 0.05 \text { y } 7 \\
\text { grados libertad se tiene un valor referencial de } \mathrm{x}^{2} \mathrm{t} \text { (tabulado) }=14.06 \text {. Los hígados examinados durante la ins- } \\
\text { pección post mortem, en las ocho semanas de control fue de } 108.6 \mathrm{lb} \text {, con una media de } 12 \text { libras por hígado, las } \\
\text { pérdidas económicas, en los hígados decomisados contabilizados en su totalidad es de USD } 217.20 \text {, con una } \\
\text { media de } 24.13 \text { USD por cada hígado contaminado. }\end{array}$ \\
\hline
\end{tabular}

Palabras clave:

\section{Abstract}

J. Selva Andina Anim. Sci. 2020; 7(2):72-80. ID of article: 071/JSAAS/2020

\section{Record from the article.}

Received February 2020

Returned May 2020

Accepted August 2020.

Available online, October 2020

Editado por:

Selva Andina

Research Society
The objective of the investigation was to determine the prevalence of hydatidosis in the liver of cattle slaughtered in the municipal bed of the city of Puyo, Pastaza province. The study consisted of post-morten inspection of the viscera, livers, of all cattle. Descriptive and inferential statistics were used to evaluate the trial, using tables with percentages, graphs, averages, coefficient of variation (CV), standard deviation and using the Chisquare test. On average, a weight of $13.57 \mathrm{lbs}$. Of seized livers was obtained with a standard deviation of 11.67 and a coefficient of variation of $85.99 \%$. There is variability in the data, this is due to the low frequency of occurrence of the disease in slaughtered cattle, of 0.05 and 7 degrees freedom, a referential value of $x 2 t$ (tabulated) $=14.06$. The livers examined during the post mortem inspection, in the eight weeks of control was $108.6 \mathrm{lb}$., with an average of 12 pounds per liver, the economic losses, in the total confiscated livers accounted for USD 217.20, with an average of USD 24.13 for each liver contaminated.

\section{Keywords:}

\section{Decomize,}

Inspection,

post-mortem,

cyst,

viscera. 


\section{Introduction}

Hydatidosis is a parasitosis that affects different domestic and wild species, in which cattle and pigs are the most prone, causing losses in production, reducing the production of meat and milk, affecting growth, and inducing the seizure of the organs in postmortem inspection. Vera et al. ${ }^{1}$ pointed out that the echinococcal gallbladder was filled with a fluid that, when ruptured, emptied into the abdominal cavity, which could cause sudden death. Galen pointed out that the preferred seat of the echinococcus was the liver. Pallas recognized the animal nature of the echinococcal vesicle and its motivation for ribbon worms. While the echinococcal gallbladder was already known in the larval stage by ancient doctors, the cestode and the eggs were discovered.

The disease is caused by the development of larvae of various species of Echinococcus spp., Such as $E$. granulosus, which is transmitted through food contaminated with the eggs of these parasites or by contact with dogs affected by the disease ${ }^{2}$.

The sample size was obtained through the formula described by, Choque ${ }^{3}$, which mentions that taking into account a $95 \%$ confidence interval and a $5 \%$ error level. The sampling was carried out on ordinary days from Monday to Saturday with an average of 10 slaughtered animals per day, the origin, breed, sex, and age being recorded in a clinical file. A macroscopic examination of the liver, lungs, and others was carried out at the time of evisceration. The results obtained were subjected to the analysis through the statistical test of Chi-square, there was no statistically significant difference between the observed frequencies, and the expected frequencies, except for the origin (by department, and provinces), so it is deduced that the age, race, and sex are not predisposing factors for the presence of this zoonotic parasitic disease ${ }^{3}$. Based on this classifica tion and given the lack of uniform criteria in the management of this disease in the country, the Aysén region workgroup decided to propose a management integral of this zoonosis, which was accepted and published as standards by the Ministry of Health in January $2016^{4}$.

In studies carried out in the city of Potosí, in the municipal slaughterhouse, 1240 bovines were observed, which arrived at this place of slaughter, in the first place data was obtained from the owners and data from the animals destined for slaughter. After the demolition of each bovine in the sector destined to giblets, the macroscopic post-mortem diagnosis was made and the information was collected in control cards to then be subjected to the Chi-square statistical test, the following results were obtained: the positivity of hydatidosis was 3.95 which means of 1240 observed samples 49 presented hydatic cysts $(\mathrm{HC})^{5}$. Important data for knowing the disease, its distribution, evaluating control and eradication plans, evaluating new diagnostic and treatment techniques. There are two critical points in which the referred macroscopic diagnosis almost invariably fails those organs in which the metacestodes are present, but not macroscopically visible, and those that are seized for presenting lesions similar to hydatidosis but of different etiolo$\mathrm{gy}^{6}$.

Hydatidosis is a parasitic disease caused by the juvenile form of helminths belonging to the genus Echinococcus spp., which affects several species of animals and man (zoonosis). The formation of vesicles with fluid under pressure in different organs of the body of the intermediate hosts makes this disease risky, important for animal and human health ${ }^{7}$. The content is the hydatic liquid that occupies the inside of the hydatid under pressure, it is clean like rock 
water and contains in suspension the hydatic sand (scolices, hooks, etc.) to be called $\mathrm{HC}$ it must be considered in addition to these elements own of the hydatid an outer wall: the adventitia formed by the reaction of the parasitized organ that tends to isolate the larva, like a foreign body, encysting it $^{8}$. Humans constitute an accidental intermediate host, which is spread by ingesting parasite eggs directly or through food contaminated by poor hygiene habits 9 .

The life cycle when a definitive host carnivore (eg, a dog, fox, or wolf) ingests cysts, which then release larvae (protoscolices) in the small intestine where they develop into adult cestodes that, 25-80 days later in depending on the species and strain of Echinococcus spp., they in turn release eggs into the environment, which leads to the permanence of the zoonotic cycle of the parasitic disease ${ }^{10}$. The genus Echinococcus represents a group of very small cestodes (flatworms) and of great importance for public health. Of the tapeworms that affect man, it is the most common of all ${ }^{11}$. The features of taxonomic interest that characterize it are, the adult measures 2 to $7 \mathrm{~mm}$, and normally it has three or four proglottids. The rostellum has two rows of hooks that differ in shape and length from the hooks of the remaining species, they are arranged in the form of two concentric crowns. The ovary is shaped like a kidney; the irregularly alternating genital pores open in the posterior half of the mature and gravid proglottids. The gravid uterus has a well-developed diverticula ${ }^{12}$.

The pathologies that show the pathogenic effects initially produced by the oncospheres and later by the metacestodes are variable depending on the intermediate host, the parasitized organs, the degree of infection, and even the virulence of the species and strains ${ }^{13}$. On the other hand, cysts can evolve towards the formation of an abscess due to infection of the gallbladder, either spontaneously due to a fissure of the wall or accidentally as a consequence of the puncture. They can also be caseified in the periphery between the cuticle and the inner face of the cyst. On the other hand, calcareous cysts contain precipitates in caseous magma ${ }^{14,15}$, it shows that the $\mathrm{HC}$ grows rapidly within the target organ, causing symptoms dependent on three basic factors. The number of HC present in the same individual, the location of a said within said organ.

In domestic animals, hydatidosis is usually asymptomatic, or the symptoms are nonspecific despite massive lung and liver infections. In slaughter animals, the only notable thing is the decline in all productions, primarily with regard to the gain of muscle tissue and modification of the milk composition with a decrease in casein, lipids, or lactose and an increase in chlorides ${ }^{16}$. The lung and liver are the most affected organs. In the case of containing protoscolices inside them, the cysts are called fertile, if they do not have them, they are sterile. Only the presence of fertile cysts would enhance the transmission of the parasitic cycle. In cattle, the fertility of cysts can vary between 0.7 and $70 \%{ }^{17}$. In goats, between 0 and $35.7 \%^{18,19}$.

Ultrasound allows to establishing the stage of the cyst based on structural alterations that characterize the different evolutionary moments of the same and that are the basis of the proposed classifications. It is also used for the evolutionary follow-up of the treated persons and to guide the puncture during the puncture, aspiration, and injection, re-aspiration (PAIR) method, which consists of four puncture, aspiration, and injection and re-aspiration procedures ${ }^{20}$.

Serological tests allow a specific diagnosis. These require the antigen/antibody reaction, which requires the host's immune response capacity and the contact of this immunocompetent system with antigens (fissure or rupture of the germ layer). They can be negative in lung cysts and in liver cysts in which the re- 
lease of immunogens into the bloodstream has not occurred or due to the presence of antigen-antibody complexes $^{21}$. They can also be caseified in the periphery between the cuticle and the inner face of the cyst. On the other hand, calcareous cysts contain precipitates in caseous magma ${ }^{22}$. In contrast, the lung, as it presents elastic characteristics, offers little resistance to the growth of the cyst, which determines a relatively rapid increase in size with the consequent appearance of clinical symptoms in a high percentage of cases ${ }^{14}$. Prevalence of macroscopic hydatidosis lesions during the 2002-2006 period in slaughterhouses in the province of Osorno, Chile. Percystic pneumonia may also occur in patients, secondary to compression of the lung parenchyma and percystic bronchi ${ }^{23}$. Ultrasound allows to establishing the stage of the cyst based on structural alterations that characterize the different evolutionary moments of the cyst and that are the basis of the proposed classifications. The objective of the study was to determine by post-mortem inspection the prevalence of hydatidosis at the liver level of cattle slaughtered in the municipal slaughterhouse of the city of Puyo.

\section{Materials and methods}

The investigation was carried out in the municipal slaughterhouse of the city of Puyo, Pastaza province, in the El Recreo neighborhood, on the way to the Tarqui parish. The geographic coordinates $1^{\circ}$ $00^{\prime \prime}$ and $2^{\circ} 40^{\prime \prime}$ of South Longitude, and $75^{\circ} 40^{\prime \prime}$ and $78^{\circ} 10^{\prime \prime}$ of West Latitude, surface $29068 \mathrm{~km}^{2}$, altitude between 300 and $1100 \mathrm{~m}$, temperature between 18 and $33^{\circ} \mathrm{C}$, warm humid tropical microclimate and annual precipitation 2000 and $4000 \mathrm{~mm}^{24}$. Location, it was in the El Recreo neighborhood, on the way to the Tarqui parish. A total of 274 livers of cattle slaughtered in the municipal slaughterhouse of Puyo were used. Animals that were on average (4 years) were taken, the total number of cattle that enter the Puyo Municipal slaughterhouse for slaughter on Monday and Wednesday, during the working hours between two in the morning until seven o'clock, middle of the morning. The total number of cattle slaughtered on Monday and Wednesday during the months of September and October 2013 was considered. The investigation was carried out with the livers of cattle slaughtered in the municipal slaughterhouse of Puyo, identifying the presence of hydatidosis. Descriptive statistics and inferential statistics were used to evaluate the trial, using tables with percentages, graphs, averages, coefficient of variation $(\mathrm{CV})$, standard deviation, and hypothesis verification using the Chi-square test.

Once the identification of the contaminated livers was made, they were quantified including the weight of each one. To determine the incidence of the disease using statistical processes, the measures of central tendency and dispersion were calculated: arithmetic means, mode, median, and standard deviation. In addition, he used a camera, knife, record sheet, among others. The operation of the slaughterhouse facilities begins with the reception process, the animals are received according to the documentation of the mobilization guide, the animals are identified, weighed, and placed in the pens, to comply with the sanitary prevention measures, and the inspection before mortem is one of them.

\section{Results}

Once the study to determine the incidence of liver cysts in cattle slaughtered in the municipal slaughterhouse of Puyo has been completed, the following 
is indicated from the results obtained. It can be seen that the total of the eight weeks of fieldwork, in the sixth week 30 livers were examined, which represents $11 \%$ of the total slaughtered cattle. In the fourth and fifth weeks, 32 livers were examined weekly, representing $24 \%$ of what was observed. In the first week, 33 livers were examined, representing $12 \%$. In the seventh and eighth weeks, 36 livers were examined weekly, representing $26 \%$, and with 13 and $14 \%$, the second and third weeks were found with 13 and 14 livers examined respectively.

\section{Table 1 Descriptive statistical measures of the livers examined}

\begin{tabular}{lr}
\hline \multicolumn{1}{c}{ Measure } & Parameter \\
\hline Measure & 34.25 \\
Typical error & 1.013304354 \\
Median & 34.5 \\
fashion & 32 \\
Standard deviation & 2.866057521 \\
Sample variance & 8.214285714 \\
Kurtosis & -1.578586011 \\
Coeficiente de asimetría & -0.13956454 \\
Rank & 8 \\
Minimum & 30 \\
Maximum & 38 \\
Sum & 274 \\
Account & 8 \\
\hline On average, 34.25 livers were examined, a standard deviation of 2.86 \\
and a coefficient of variation of $8 \%$
\end{tabular}

It is observed that a total of 274 livers examined during the eight weeks, the highest peaks are in the third and second week where 38 and 37 livers were examined respectively, while the lowest peak is seen in the sixth week with 30 livers. The average number of contaminated livers. In (table 1) the standard deviation of 2.86 and a coefficient of variation of $8 \%$. A total of eight weeks of fieldwork is appreciated, the second and third week there are no contaminated livers, during four weeks a contaminated liver per week is detected, representing $44 \%$ of the sample.
In addition, it was detected that a total of 9 livers contaminated during the eight weeks, (figure 1) in the seventh week the highest peak was obtained where a seizure of 3 livers contaminated by $\mathrm{HC}$ was obtained, while the lowest peak was in weeks two and three where there were no contaminated livers. On average, a weight of $13.57 \mathrm{lb}$., of seized livers was obtained with a standard deviation of 11.67 and a coefficient of variation of $85.99 \%$. The average economic losses (table 2) is \$27.15 with a standard deviation of 23.34 and a coefficient of variation of $85.99 \%$. In the percentages of both the coefficient of variation of the weight of contaminated livers, as well as the economic losses are higher than $20 \%$, there is variability in the data, this is due to the low frequency of occurrence of the disease in slaughtered cattle.

\section{Figure 1. Livers examined during the 8 weeks}



In (table 3) of 0.05 and 7 degrees of freedom there is a referential value of $\mathrm{x} 2 \mathrm{t}$ (tabulated) $=14.06$. With a significance level of 0.05 and 7 degrees of freedom, there is a reference value of $\mathrm{x} 2 \mathrm{t}$ (tabulated) $=14.06$. Considering these data and after performing the mathematical calculation of the Chisquare, a value of 6.38 was obtained, which indicates that $\mathrm{x} 2 \mathrm{c}$ (calculated) is less than $\mathrm{x} 2 \mathrm{t}$. 
Table 2 Descriptive statistical measures of weight in pounds and economic losses

\begin{tabular}{lrr}
\hline Measure & Weight in lb & Economic losses \\
\hline Measure & 13.575 & 27.15 \\
Typical error & 4.127380266 & 8.254760531 \\
Median & 12.3 & 24.6 \\
fashion & 0 & 0 \\
Standard deviation & 11.6739943 & 23.34798859 \\
Sample variance & 136.2821429 & 545.1285714 \\
Kurtosis & 1.05695495 & 1.05695495 \\
Asymmetry coefficient & 0.816850598 & 0.816850598 \\
Rank & 35.9 & 71.8 \\
Minimum & 0 & 0 \\
Maximum & 35.9 & 71.8 \\
Sum & 108.6 & 217.2 \\
Account & 8 & 8 \\
\hline \multicolumn{2}{c}{ On average, 34.25 livers were examined, with a minimum of 30 and a maximum of 38,} \\
\multicolumn{2}{c}{ a standard deviation of 2.86 and a coefficient of variation of 8\%. }
\end{tabular}

Table 3 Chi-square calculation measure (Weeks)

\begin{tabular}{crrrrr}
\hline Measure (Weeks) & \multicolumn{1}{c}{ fo } & \multicolumn{1}{c}{ Fe } & fo-fe & \multicolumn{1}{c}{ (fo-fe) $^{\mathbf{2}}$} & \multicolumn{1}{c}{ (fo-fe) $^{\mathbf{2}} / \mathbf{f e}$} \\
\hline 1 P & 1 & 1.08 & -0.08 & 0.0064 & 0.005925926 \\
1 N & 32 & 31.92 & 0.08 & 0.0064 & 0.000200501 \\
2 P & 0 & 1.22 & -1.22 & 1.4884 & 1.22 \\
2 N & 37 & 35.78 & 1.22 & 1.4884 & 0.41598658 \\
3 P & 0 & 1.25 & -1.25 & 1.5625 & 1.25 \\
3 N & 38 & 36.7521 & 1.25 & 1.5625 & 0.042517007 \\
4 P & 1 & 1.05 & -0.05 & 0.0025 & 0.002380952 \\
4 N & 31 & 30.95 & 0.05 & 0.0025 & $8.07754 \mathrm{E}-05$ \\
5 P & 2 & 1.05 & 0.95 & 0.9025 & 0.85952381 \\
5 N & 30 & 30.95 & -0.95 & 0.9025 & 0.029159935 \\
6 P & 1 & 0.99 & 0.01 & 0.0001 & 0.00010101 \\
6 N & 29 & 24.01 & -0.01 & 0.0001 & $3.44709 \mathrm{E}-06$ \\
7 P & 3 & 1.18 & 1.82 & 3.3124 & 2.807118644 \\
7 N & 33 & 34.82 & -1.82 & 3.3124 & 0.095129236 \\
8 P & 1 & 1.18 & -0.18 & 0.0324 & 0.027457627 \\
8 N & 35 & 34.82 & 0.18 & 0.0324 & 0.0009305 \\
Total & $\mathbf{2 7 4}$ & $\mathbf{2 7 4}$ & $\mathbf{X}^{2}$ calculado & $\mathbf{6 . 3 8 2 1 2 8 0 2 9}$ \\
\hline
\end{tabular}

The total calculated $\mathrm{x} 2=$ With a significance level of 0.05 and 7 degrees of freedom, there is a referential value of $\mathrm{x} 2 \mathrm{t}$

(tabulated $)=14.06$. Considering these data and after performing the mathematical calculation of the Chi square, a value of 6.3821 was obtained,

which indicates that $\mathrm{x} 2 \mathrm{c}$ (calculated) is less than $\mathrm{x} 2 \mathrm{t}$

\section{Discussion}

During the research work within the slaughterhouse, a total of 9 positive bovines were obtained, that is, $3.29 \%$, if we compare with the research carried out in Potosí, work carried out during the months of September, October and November of a total out of 1240 bovines, an incidence of $3.95 \%$ was detected in the municipal slaughterhouse of the city of Poto$\mathrm{si}^{25}$, while our study carried out in the Camal Mu- nicipal de Puyo the total number of animals inspected was 274, developed during the months of September and October, due to various factors such as greater number of slaughtered animals, environmental characteristics of the year, type of management, type of terrain among others. On the other hand, an investigation carried out analyzed organ samples from 432 cattle from 13 establishments (6 from Neuquén and 7 from Chubut). 96 animals (22.2\%) presented at least one lesion compatible with hyda- 
tidosis, 50\% pulmonary, $4.2 \%$ hepatic, and $45.8 \%$ hepato-pulmonary ${ }^{26}$. The microscopic analysis of the cyst fluid (figure 2), belonging to a subset of 42 animals, did not show the presence of protoscolices, and 25 germinative membranes were found. Cruzat et al. ${ }^{27}$ also reported studies with a prevalence of findings compatible with hydatidosis in the 218 cattle evaluated of $12.4 \%(n=27)$. With a significance level (table 3 ) of 0.05 and 7 degrees of freedom, there is a referential value of $\mathrm{x} 2 \mathrm{t}$ (tabulated) $=$ 14.06. Rau et al. ${ }^{26}$ mention in their trial that the hydatid prevalence and of positive establishments and the confidence interval $(95 \% \mathrm{CI})$ were estimated. 42 samples of HC content were taken and fertility was evaluated, variables associated with the presence of $\mathrm{HC}$ were studied. Prevalence ratio (PR) with 95\% CI was calculated. Considering these data and after performing the mathematical calculation of the Chi-square, a value of 6.38 was obtained, which indicates that $\mathrm{x} 2 \mathrm{c}$ (calculated) is less than $\mathrm{x} 2 \mathrm{t}$. Regarding the economic losses of seized livers, a total of \$ 217.2 was obtained, a total of 217.2 dollars was obtained, corresponding to 108.6 pounds of livers. Coinciding with studies carried out over 11 months, the animals affected by differ significantly ( $p$ $<0.001$ ) between the slaughterhouses except the month of July, while the total losses due to seizures of affected livers showed significant differences ( $p$ $<0.001)$ in all the months for the evaluated peri$\mathrm{od}^{25}$. Hydatidosis in the livers of cattle slaughtered in the municipal slaughterhouse of the city of Puyo, were 9 positive cases that represents $3.29 \%$ of a total of 274 livers examined during the post-mortem inspection, in the eight weeks of investigation. The weight of livers contaminated by hydatidosis during the eight weeks of investigation was 108.6 pounds, with a mean of 12 pounds per liver. The economic losses in the seized livers were US \$217.20, with an average of US \$24.13 for each contaminated liver during the eight weeks of investigation.

\section{Funding Source}

Faculty of Agricultural Sciences and thesis student.

\section{Conflicts of interest}

The investigation was carried out in the municipal slaughterhouse of the city of Puyo-Pastaza and does not present conflicts of interest. In addition, the present study has met the ethical standards for handling animals.

\section{Acknowledgements}

The authors thank the Technical University of Ambato, Faculty of Agricultural Sciences, and the municipal slaughterhouse of the city of Puyo - Pastaza for the technical, scientific and logistical support provided to this research

\section{Ethical aspects}

The institutional ethics committee for the use of experimental animals was built under a regulation established within the Faculty of Agricultural Sciences, whose members are teachers and students. In addition, the present study has met the ethical standards for handling animals in research work.

\section{Cited literature}

1. Vera G, Venturelli F, Ramírez J, Venturelli A. Hidatidosis humana. Cuad Cir [Internet]. 2003 [citado 5 de moviembre de 2019];17(1):88-94. 
DOI: https://doi.org/10.4206/cuad.cir.2003.v17n1 $-14$

2. Budke CM, Deplazes P, Togerson PR. Global socioeconomic impact of cystic echinococcosis. Emerg Infect Dis 2006;12(2):296-303. DOI: https://doi.org/10.3201/eid1202.050499

3. Choque M. Determinación de quistes hidatídicos en bovinos faenados en el Matadero Municipal de Tupiza. [tesis licenciatura]. Potosí: Universidad Autónoma Tomás Frías; 1998.

4. Pinto PP. Diagnóstico, tratamiento y seguimiento de la hidatidosis. Rev Chil Cir 2017;69(1):94-98. DOI: https://doi.org/10.1016/j.rchic.2016.10.001

5. Flores M. Prevalencia de hidatidosis en ganado bovino faenado en el Matadero Municipal de la ciudad de Potosí [tesis licenciatura]. Potosí: Universidad Autónoma Tomás Frías; 2012.

6. Dubarry JR, Errea AL, Maria AE, Muñoz C, Kenny O, Véspoli Pucheu MV, et al. Hidatidosis bovina: Contrastación de los diagnósticos macroscópico y microscópico. Cienc Vet 2011; 13(1):35-45. DOI: http://doi.org/10.19137/ cienvet2013-1513

7. Acha P, Szyfres B, editores. Zoonosis y enfermedades transmisibles comunes al hombre y a los animales: Volumen III Parasitosis. $3^{\text {ra }}$ ed. Washington D.C: Organización Panamericana de la Salud; 2003. 1-173, 222-4 p.

8. Sánchez Acedo C. Hidatidosis. Pequeños rumiantes [Internet]. 2002 [citado 5 de octubre de 2019]; 32;3(2):9-15. Recuperado a partir de: http://www. produccion-animal.com.ar/sanidad_intoxi caciones_metabolicos/parasitarias/Hidatidosis/02hidatidosis.pdf

9. Andersen FL, Ouhelli H, Kachani M, editors. Compendium on cystic echinococcosis in Africa and in Middle Eastern countries with special reference to Morocco [Internet]. Provo, UT, USA: Brigham Young University; 1997 [citado 22-de octubre de 2019]. Recuperado a partir de: https://catalogo.biblioteca.utad.pt/cgi-bin/koha/ opac-detail.pl?biblionumber $=10467$

10. Moreno García B, editor. Higiene e inspección de carnes. Bases científicas y legales de los dictámenes de mataderos [Internet]. Madrid: Ediciones Díaz de Santos S.A; 2003 [citado 22-de octubre de 2019]. 65 p. Recuperado a partir de: https://www.editdiazdesantos.com/libros/moreno -garcia-benito-higiene-e-inspeccion-de-carnesvol-ii-L03005730103.html

11.Cordero del Campillo M, Rojo Vázquez FA, Martínez Fernández AR, Sánchez Acedo MC, Hernández Rodríguez S, Navarrete López-Cozar I, et al, editores. Parasitología general [Internet]. Madrid: McGraw-Hill, Interamericana; 2007 [citado 22-de octubre de 2019]. 178 p. Recuperado a partir de: https://kupdf.net/download/m-cordero -y-f-rojo-2007-parasitologia-general_59b40c01dc 0d60e050568edc_pdf

12.Guarnera EA, editor. Hidatidosis en Argentina: carga de enfermedad. $1^{\text {ra }}$ ed. Buenos Aires: Organización Panamericana de la Salud: 2009.

13.Salazar, S. 2002. Equinococosis, zoonosis parasitaria. Bucaramanga, CO. 231-77 p.

14. Rosas Hinostroza HP. Prevalence of macroscopics injuries of hydatidosis during period 20022006 in slaughterhouses of the province of Osorno, Chile. Rev Electrón Vet [Internet]. 2010 [citado 5 de octubre de 2019]; 11(12):30-5. Recuperado a partir de: https://www.researchgate. net/publication/49611498_Prevalencia_de_lesion es_macroscopicas_de_hidatidosis_durante_el_pe riodo_2002-006_en_mataderos_de_la_provincia _de_Osorno_Chile__Prevalence_of_macros copics injuries of hydatidosis during period 200 $\underline{2-2}$

15.Zúñiga Arce I. Investigación clínica y experimental de la hidatidosis en el municipio de Zacateca, 
México. [tesis doctoral]. [Mexico]: Universidad Nacional Autónoma de México; 1991 [citado 26 de noviembre de 2019]. Recuperado a partir de: https://repositorio.unam.mx/contenidos/investiga cion-clinica-epidemiologica-y-experimental-dela-hidatidosis-y-equinococosis-en-el-municipiode-zacatecas-63415?c=480D8b \&d=false \&q=*:* $\underline{\mathrm{i}=1 \& \mathrm{v}=1 \& \mathrm{t}=\text { search } \_ \text {o } \mathrm{as}=0}$

16.Delgado R. Hidatidosis una realidad: pasado y presente. Facultad de Medicina Veterinaria: Universidad Nacional Mayor de San Marcos; 2009.

17.Faraji R, Javadi GR, Barshahi PM, Ahmadian F, Sarebanhassanabadi M, Firoozabadi AD, et al. Prevalence of hydatid cyst in slaughtered livestock in Kermanshah (West Iran). Adv Microbiol 2015;5(4):252-7. DOI: https://doi.org/10.4236/ aim.2015.54023

18.Founta A, Chliounakis S, Antoniadou Sotiriadou K, Koidou M, Bampidis V. Prevalence of hydatidosis and fertility of hydatid cysts in food animals in Northern Greece. Vet Ital 2016;52(2):123-7. DOI: https://doi.org/10.12834 /vetlt.123.347.2

19. Saeed I, Kapel C, Saida LA, Willingham L, Nansen P. Epidemiology of Echinococcus granulosus in Arbil province, northern Iraq, 1990-1998. J Helminthol 2000;74(1):83-8. DOI: https://doi.org /10.1017/s0022149x00000111

20.McManus DP, Gray DJ, Zhang W, Yang Y. Diagnosis, treatment, and management of echinococcosis. BMJ 2012; 344:e3866. DOI: https://doi. org/10.1136/bmj.e3866

21.Muñoz P. Diagnóstico y tratamiento de la hidatidosis. Rev Chil Infect 2007;24 (2):153-4. https:// doi.org/10.4067/S0716-10182007000200011
22.Brunetti E, Junghanss T. Update on cystic hydatid disease. Curr Opin Infect Dis 2009; 22(55):497-502. DOI: https://doi.org/10.1097/ QCO.0b013e328330331c

23.Hidatidosis. En: Libro azul de infectología pediátrica. $3^{\text {ra }}$ ed. Actualizada. Buenos Aires: Sociedad Argentina de Pediatría; 2007. p. 1083-6.

24.Monitoreo Meteorológico e Hidrométrico [Internet]. Recursos Naturales Aguas Y ParamosDirección de Recursos Hídricos y Conservación Ambiental. 2014 [citado 5 de octubre de 2014]. Recuperado a partir de: http://rrnn.tungurahua. gob.ec/\#/programas/ver/51c9f93fbd92ea3416000 $\underline{001}$

25.Palacio Collado D, Bertot Valdés J, Beltrao Molendo M, Vázquez Gil A, Ortíz Vásquez R, Fortune Nápoles C. Pérdidas económicas y prevalencia de Fasciola hepatica en bovinos sacrificados en dos provincias cubanas. Rev MVZ Córdoba 2020; 25(1):e1610. DOI: https://doi.org/10. 21897/rmvz.1610

26.Rau E, Rivero M, Tisnés A, Fernández R. Epidemiologia de hidatidosis en bovinos de consumo en la Comarca Andina del Paralelo 42. Rev Argent Salud Publica 2019;10(41):22-7.

27. Cruzat A, Silva A, Morales P, Carmona H. Characterization of the prevalence of findings compatible with hydatidosis and fertility of hydatid cysts in cattle of a slaughterhouse in Curicó, Chile. Rev Investig Vet Perú 2019;30(2):874-82. DOI: https://doi.org/10.15381/rivep.v30i2.16087 neutral regarding jurisdictional claims published on maps and institutional affiliations. 